\title{
Farklı Tarımsal Atıkların Ganoderma lucidum (Reishi mantarı) Yetiştiriciliğinde Verim ve Kalite Üzerine Etkisi
}

\author{
Yasin Burak HAL ${ }^{1}$, Mahmut YARAR ${ }^{2}$, Ecem KARA $^{1}$, Gökhan BAKTEMUR ${ }^{3}$, \\ Hatıra TAŞKIN ${ }^{1 *}$
}

ÖZ

$\mathrm{Bu}$ çalışmada, Ganoderma lucidum (Reishi mantarı) yetiştiriciliğinde, farklı yetiştiricilik ortamlarının verim ve kalite üzerine etkilerinin test edilerek, en uygun substrat materyallerinin ve bunların karışım oranlarının belirlenmesi hedeflenmiştir. G. lucidum'un tohumluk miselleri sekiz farklı yetiştiricilik ortamına aşılanmıştır. Çalışmada; yetiştirme ortamlarının $\mathrm{pH}$ ve nem içeriği üç farklı dönemde belirlenmiş, misel sarım hızı, verim, biyolojik etkinlik ve ortalama ağılık açısından ortamlar karşılaştırılmıştır. Çalışma sonucunda, en yüksek verim ve biyolojik etkinlik B4 (2 mısır koçanı +1 buğday kepeği) yetiştiricilik ortamından elde edilmiştir. En kısa misel sarım süresi ise B3 (1 meşe kaba talaş1 +1 yer fisttğı kabuğu +1 buğday kepeği) ve B6 ( 2 asma budama atı̆̆ $1+1$ kepek) ortamlarında kaydedilmiştir.

Anahtar Kelimeler: Reishi mantarı, Ganoderma lucidum, yetiştiricilik, tarımsal atık.

\section{Effect of Different Agricultural Wastes on Yield and Quality in Cultivation of Ganoderma lucidum (Reishi mushroom)}

\section{ABSTRACT}

In this study, it was aimed to determine the most suitable substrate materials and their mixing ratios by testing the effects of different substrates on yield and quality of Ganoderma lucidum (Reishi mushroom). The spawn of G. lucidum was inoculated on eight different growing mixtures. In the study, $\mathrm{pH}$ and moisture content were determined in the growing mixtures at three different periods and the growing mixtures were compared in terms of mycelia development time, yield, biological efficiency and average mushroom weight. At the end of study, the highest yield and biological efficiency were obtained from B4 (2 corncob +1 wheat bran) growing mixture. The shortest mycelia development time was recorded in B3 (1 oak sawdust +1 peanut shell + wheat bran) and B6 (2 vine pruning waste +1 wheat bran) growing mixtures.

Keywords: Reishi mushroom, Ganoderma lucidum, cultivation, substrat.

ORCID ID (Yazar sirasına göre)

0000-0002-5479-8113， 0000-0003-3991-5649， 0000-0002-0118-2673，0000-0002-0362-5108, 0000-0002-1784-4731

\footnotetext{
Yayın Kuruluna Geliş Tarihi: 26.10.2021

Kabul Tarihi: 20.12.2021

${ }^{1}$ Çukurova Üniversitesi, Ziraat Fakültesi, Bahçe Bitkileri Bölümü, 01330 Adana

${ }^{2}$ Çukurova Üniversitesi, Fen Bilimleri Enstitüsü, Biyoteknoloji Anabilim Dalı, 01330 Adana

${ }^{3}$ Sivas Bilim ve Teknoloji Üniversitesi, Tarım Bilimleri ve Teknoloji Fakültesi, Bitkisel Üretim ve Teknolojileri Bölümü, Sivas

*E-posta: hatirataskin1@gmail.com
} 


\section{Farklı Tarımsal Atıkların Ganoderma lucidum (Reishi mantarı) Yetiştiriciliğinde Verim ve Kalite Üzerine Etkisi}

\section{Giriş}

Mantarlar, çok eski zamanlardan beri değerli bir besin maddesi olarak kabul edilmiştir. Romalılar; mantarların ilkbahar yağmurlarından sonra çıkışına, Zeus'un kendilerine bir hediyesi olduğuna dair anlamlar yüklemişlerdir (Lincoof, 1988). Asya ülkelerinde ise geleneksel tıpta ve krallara özgü yemeklerde kullanılmışlardır. Günümüzde ise mantarlar, çok farklı endüstrilerde kullanılmaya başlanmıştır. Bu endüstrilerin başında, gida ve ilaç sanayisi gelmektedir. Mantarlar, besin içeriği bakımından oldukça önemli gıdalardır. Türlere göre besin içeriği oranı değişmekle beraber, mantarların büyük bir kısmı \%88-91 oranında su ve \%9-12 içerirler. Kuru madde; içerisindeki proteinler, karbonhidratlar, vitaminler, kalsiyum, potasyum, fosfor, demir ve liflerden meydana gelir (Matilla ve ark., 2002). Mantarlar, ayrıca çok önemli protein kaynağıdırlar. Protein oranı hayvansal gıdalardaki kadar yüksek olmasa bile, birçok sebze grubundan fazladır. Proteinler, mantarların kuru ağırlığının \%10-40'lık kısmını oluşturur ve mantar proteini tüm esansiyel aminoasitleri içerdiği için kaliteli ve aynı zamanda sindirilebilirdir. Metiyanin, sistin ve sülfür aminoasitlerini de az miktarda içerirler (Smith ve ark., 2002). İçerdiği kaliteli aminoasitler nedeniyle, vegan ve vejeteryan tüketiciler için önemli besin gıdasıdır. Ayrıca, yapısındaki eser miktarda bulunan yağlar nedeniyle, düşük kalorili lezzetli diyet ürünüdürler (Chang ve Buswel, 1996).

Dünyada kültürü yapılan önemli mantar türleri; Agaricus bisporus (beyaz şapkalı mantar), Pleurotus sp. türleri ve Shiitake'dir. Ganoderma lucidum türünün yetiştiriciliği ise gün geçtikçe artmaktadır (Yakupoğlu ve Pekşen, 2011). G. lucidum, hem 1lıman hem de tropik bölgelerde yetişebilen egzotik bir mantar türüdür. G. lucidum; lamelsiz, porlu ve tıbbi özelliklere sahip kültüre alınabilen bir mantardır (Yakupoğlu ve Pekşen, 2011). Bazidiyokarpı saplı, ikiye ayrılmış ya da böbrek şeklinde olup, kalın, kuru ve gelişirken sarıdır. Olgunlaşma devresinde, kenarları ön yüzde parlak görünüm ile birlikte kahverengiye dönmektedir. Kenarları, ince ya da kesilmiş yapıdadır. Sapı; kalın, siyahtır ve sonradan morumsu kahverengiye döner. Gözenekleri önce siyah olup, daha sonra açık kahverengiye dönmektedir. G. lucidum, Asya kıtasında çok eski zamanlardan beri bilinmektedir. Çin, Japonya ve Kore'de tıbbi özelliğinden dolay1 geleneksel tipta uzun yillardan beri kullanılmaktadır. Özellikle Çin ve Japonya kültüründe, önemli bir yere sahiptir. Çinliler ve Koreliler tarafindan Ling-Zhi veya Ling-Chi (ölümsüzlük mantarı), Japonya'da ise Reishi veya Mannentake (10000 yıl mantarı) olarak adlandırılmaktadır. Günümüzde, Kuzey Amerika başta olmak üzere, dünyanın birçok yerinde üretimi ve tüketimi artmaktadır (Zhao ve Zhang, 1994). Çin ve Japon kaynaklarında geçmişten günümüze kadar, bu mantarın hastalıklardan koruduğuna dair bilgiler yer almıştır.

G. lucidum'un üretimine yönelik sayısal veriler bulunmamaktadır. Yalnızca 1980'li yıllardan sonra, üretiminin arttığ 1 , dünyada üretimimin 1995 yılında 500 ton iken, 2005 yılinda 6 bin tona çıktığı bilinmektedir (Anonim, 2019). $G$. lucidum doğada nadir olarak yetiştiğinden, toplayıcılık şeklinde ticari kullanımı pek mümkün olmamaktadır. $\mathrm{Bu}$ nedenle, kültüre alınmış ve odun kütüklerinde, bazı tarımsal atıkların karışımından oluşan plastik torbalarda ve şișe kültüründe üretilmeye başlanmıștır. Ülkemiz mikobiotasında bulunmasına rağmen, G. lucidum'a yönelik çalışmalar sınırlıdır (Yen, 2008; Erkel, 2009a, 2009b; Peksen ve Yakupoglu, 2009; Yakupoğlu ve Pekşen, 2011; Bozok ve ark., 2016).

$\mathrm{Bu}$ bilgiler 1şığında bu çalışmada; dünyada alternatif tıpta yaygin olarak kullanılan $G$. lucidum mantarının Türkiye'de farklı tarımsal atıklarda yetiştirilmesi ve $G$. lucidum yetiştiriciliğinde en iyi verim ve kaliteyi sağlayan substrat karışımının belirlenmesi amaçlanmıştır.

\section{Materyal ve Yöntem}

Araştırma, 2019-2020 yılları arasında, Çukurova Üniversitesi Ziraat Fakültesi Bahçe Bitkileri Bölümü'ne ait Prof. Dr. Saadet BÜYÜKALACA Doku Kültürü laboratuvarı ve tam iklim kontrollü mantar yetiştirme 


\section{Farklı Tarımsal Atıkların Ganoderma lucidum (Reishi mantarı) Yetiştiriciliğinde Verim ve Kalite Üzerine Etkisi}

odalarında yürütülmüştür. Araştırmada kullanılan G. lucidum tohumluk miselleri, Atatürk Bahçe Kültürleri Merkez Araștırma Enstitüsü (Yalova)'nden temin edilmiştir.

Denemede tarımsal atıklar olarak meşe kaba talaşı, asma budama atığı, yer fistığı kabuğu ve misır koçanı kullanılmış ve bu atıklar kendi aralarında farklı oranlarda karıştırılmıştır. Substrat ana maddelerine ek olarak, buğday kepeği ve soya unu ilavesi de yapılmıştır. Meşe kaba talaşı Mersin'den, mısır koçanı Adana'da mısır üretimi yapan özel firmalardan, yer fistığ kabuğu yer fistığı işleyen özel bir firmadan, asma budama atığ1 Mersin'de üretim yapılan yerlerden alınmış, atıklara eklenen buğday kepeği ve soya unu piyasadan satın alınmıştır. Denemede kullanılan tarımsal atıkların 2:1 ve 1:1:1 oranlarında ağırlı üzerinden kepekle karışımları, aşağıda belirtilen şekilde olmuştur:

- Meşe Kaba Talaşı (K)

- 2 Meşe Kaba Talaşı + 1 Kepek (B1)

- 2 Yer Fistığ1 Kabuğu+1 Kepek (B2)

- 1 Meșe Kaba Talaşı + 1 Yer Fistı̆̆ 1 Kabuğu + 1 Kepek (B3)

- 2 Misır Koçanı + 1 Kepek (B4)

- 1 Meşe Kaba Talaşı +1 Misır Koçanı +1 Kepek (B5)

- 2 Asma Budama Atığ +1 Kepek (B6)

- 1 Meşe Kaba Talaş1 + 1 Asma Budama Atığ $1+1$ Kepek (B7)

Tüm bitkisel atıklar önce ögütülmüş, sonra nem içerikleri uygun olana kadar su dolu kaplarda belli bir süre bekletilmiştir. Nemlendirme işlemi tamamlandıktan sonra $\mathrm{pH}$ ayarlaması yapılmış, yetiştiricilik ortamlarının $\mathrm{pH}$ 'sı uygun olmadığı takdirde kireç ilavesi gerçekleştirilmiştir.

Hazırlanan yetiştiricilik ortamlanı, yüksek sıcaklığa dayanıklı polipropilen torbaların her birisine $1 \mathrm{~kg}$ olacak şekilde doldurulmuştur. Torbaların ağzı lastikle bağlanarak sterilizasyon için otoklavda $121^{\circ} \mathrm{C}$ 'de $1.2 \mathrm{~atm}$ basınçta 90 dakika süre ile sterilize edilmiș, sonrasında kompost materyalleri soğumaya bırakılmıștır. Misel aşılama işlemi ise 1 kiloluk torbalara yaklaşık 25-30 g tohumluk misel olacak şekilde doku kültürü laboratuvarında, steril kabin içerisinde yapılmıştır.
Misel aşılaması yapılan yetiştiricilik torbaları, $25-27^{\circ} \mathrm{C}$ ve $\% 70-80$ nem içeren mantar yetiștirme odalarına alınarak, misel gelişimi beklenmiştir. Misel gelişimi sağlandıktan sonra, sicaklık $25 \pm 1{ }^{\circ} \mathrm{C}^{\prime}$ ye ayarlanmıştır. Mantar oluşumunun başlaması ile odanın havalandırmasına dikkat edilmiş, yetiştiricilik ortamlarının kurumasını önlemek için nem seviyesi \%90-95 arasında tutulmuştur. Nemlendirme, bu amaçla kullanılan bir nem cihazı ile otomatik olarak yapılmıştır. Yetiștiricilik torbaları mantar yetiştirme odalarına alınmadan bir hafta önce, odalar iyice temizlenerek ilaçlanmış ve havalandırılmıştır. Ganoderma mantarı misel gelişim aşamasında 1şık istemediği için, bu aşamada yetiștiricilik odası karanlık tutulmuştur. Ürün aşamasında ise 40 watt'lık floresan lamba 12 saat açık tutularak ve 200 lüx şiddetinde aydınlatma sağlanmıştır. Yetiştiricilik torbalarında misel sarımı tam olarak gerçekleştiğinde, mantar taslaklarının (primordium) oluşumunu teşvik etmek için, torbalar 5'er cm genişliğinde steril bir bistüri ile kesilerek torbaların ağızları açılmıştır. Mantarların büyük bir kısmı aynı büyüklüğe geldiğinde, hasat yapılmaya başlanmıştır.

Biyolojik etkinlik oran1, toplam verim ve mantar kalitesi ile ilgili ölçümler, Ağaoğlu ve ark. (1992) ve İlbay (1994)'a göre yapılmıștır. Misel sarım hızını belirlemek için, bütün uygulamalara misel aşılaması ile birlikte, torbanın her tarafinı miseller sarıncaya kadar geçen süre gün olarak hesaplanmıştır. Uygulamaların her biri için yüzde biyolojik etkinlik oranı, aşağıdaki şekilde hesaplanmıştır (Shen ve Royse, 2002).

$\mathrm{BEO}(\%)=(\mathrm{TMA}(\mathrm{g}) \times 100) / \mathrm{KMA}$

\%BEO: Yüzde biyolojik etkinlik oranı

TMA: Taze mantar a $\breve{g ̆}_{1}{ }_{1} \breve{g}_{1}$

KMA: Ortamın kuru ağırlığı

Denemedeki bütün uygulamalar ve tekerrürlerden ayrı ayrı günlük hasatlar yapılarak elde edilen ürünler, $\pm 0.01 \mathrm{~g}$ duyarlılıkta terazide tartılmıştır. Hasat döneminin sonlanmasını takiben alınan verim değerlerinin toplanması ile her uygulama için elde edilen toplam verim miktarı ortaya çıkarılmıştır. Mantar ağırlığı, örneklerin $\pm 0.01 \mathrm{~g}$ duyarlılıktaki terazide tartılması ile g olarak 


\section{Farklı Tarımsal Atıkların Ganoderma lucidum (Reishi mantarı) Yetiştiriciliğinde Verim ve Kalite Üzerine Etkisi}

belirlenmiştir. Mantar örneklerinin ölçümleri $\pm 0.1 \mathrm{~mm}$ duyarlılıktaki kumpas ile yapılmış ve ortalamaları hesaplanmıştır. Üretimin birinci flaşından alınan taze mantar örneklerinde \% kuru madde miktarı, örneklerin önce $0.01 \mathrm{~g}$ duyarlılıktaki hassas terazide tartılması, daha sonra kurutulmasi ve tekrar tartılmasi ile belirlemiştir. Üretimin birinci flaşından alınan ve kurutulup ögütülen mantar örneklerinde azot tayini modifiye edilmiş Kjeldahl yöntemine göre yapılmıştır (Kacar, 1972). Protein miktarı ise bulunan azot değerinin 6.25 faktörüyle çarpılması ile hesaplanmış ve \% olarak ifade edilmiştir (Bilgir ve Boztok, 1983).

Tarımsal atıkların özelliklerinin belirlenmesi amacı ile yapılan analizlerde, yetiştirme ortamlarının hazırlı̆̆ında ilk olarak $\mathrm{pH}$ ve $\%$ nem değerleri belirlenmiştir. Bu uygulamalar, sterilizasyon sonrası, misel gelişimi tamamlandiktan sonra ve hasat sonunda olmak üzere 3 farklı dönemde yapılmıştır. $\mathrm{pH}$ analizinde, her uygulama için $10 \mathrm{~g}$ örnek tartılmıştır. Üzerine $100 \mathrm{~mL}$ saf su eklenerek 1.5 saat bekletildikten sonra, karışımın suyu süzülerek $\mathrm{pH}$ metre ile ölçüm gerçekleştirilmiştir. Nem içeriği tayini için, alınan örneklerde her uygulama için yaş ağırlıklar belirlenmiş ve sonrasında $65^{\circ} \mathrm{C}$ 'ye ayarlı etüvde sabit ağırlığa gelinceye kadar kurutulmuştur. Kuru ağırlıkları belirlendikten sonra, bulunan değerler 100'den çıkarılarak ortamların \% nem içerikleri belirlenmiştir.

Deneme, tesadüf parselleri deneme desenine göre 3 tekerrürlü ve her bir tekerrürde 3 torba olacak şekilde yürütülmüş̧ür. Elde edilen veriler, JMP istatistik paket programında tesadüf parselleri deneme desenine göre analiz edilmiştir. Yüzde değerler, açı değerlerine çevrilerek istatistik analiz uygulanmıştır. Farklılığın istatistiksel olarak önemli olduğu verilere, LSD testi uygulanarak harflendirme yapılmıştır.

\section{Bulgular ve Tartışma Mantarının Misel Sarım Süresi}

Farklı Ortamlara Aşılanmış Reishi

Misel sarım süresi; misel kalitesine, odanın nemi ve sıcaklığı gibi ekolojik koşullara ve misel ekiminin yapıldığ 1 ortamların özelliklerine bağlı değişiklik gösterebilmektedir
(Sánchez, 2004). Sunulan bu çalışmada, misel sarımı B2 (2 Yer Fistı̆̆1 Kabuğu + 1 Kepek) ortamı hariç diğer tüm ortamlarda gerçekleşmiştir (Çizelge 1).

Deneme sonunda, misel sarım süresi en kısa 28 gün ile B3 (1 Meşe Kaba Talaşı + 1 Yer Fistığ1 Kabuğu + 1 Kepek) ve B6 (2 Asma Budama Atığ $1+1$ Kepek) ortamlarında gerçekleşmiştir. En uzun misel sarım süresi ise yaklaşık 44 gün ile K (Meşe Kaba Talaşı) ortamında gözlemlenmiştir. Veena ve Pandey (2011) tarafindan G. lucidum mantarında yapılan bir çalışmada, misel sarım süresi 18.8 ile 22.8 gün arasında değişmiştir. Denenen beş ortamda (22.5 talaş : 67.5 çeltik samanı : 10 pirinç kepeği, 45 talaş : 45 çeltik samanı : 10 pirinç kepeği, 67.5 talaş : 22.5 çeltik samanı : 10 pirinç kepeği, 90 talaş : 10 pirinç kepeği; 90 çeltik samanı : 10 pirinç kepeği), misel gelişim hızında önemli bir değişiklik olmamıştır. Gurung ve ark. (2012) tarafindan gram unu, buğday kepeği, mısır unu ve pirinç kepeği içeren Shorea robusta talaş1 (35 gün) ve Alnus nepalensis talaşı (30 gün) ile hazırlanan substrat karışımlarında, G. lucidum mantarında misel gelişim süresi 30-35 gün olarak bulunmuştur. Jeewanthi ve ark. (2017) tarafindan kauçuk, mango, jak meyvesi, tespih ağacı, kauçuk : mango, jak meyvesi ve kauçuk: tespih ağacı gibi farklı talaş türü ve karışımlarında $G$. lucidum mantarında misel gelişim süresi 25.4 (kauçuk) ile 34.2 (jak meyvesi) gün arasında değişmiştir. Atila (2020) tarafindan G. lucidum mantarında yapılan bir çalışmada; buğday samanı, ayçiçeği küspesi, pamuk tohumu küspesi, soya samanı, fasulye samanı, meşe talaşı ve kavak talaşı gibi farklı substrat malzemelerinde, süre 14.2 (buğday samanı) ile 18.2 gün (pamuk tohumu küspesi) arasında değişmiştir. Yakupoğlu ve Pekşen (2011) tarafından ise misel gelişim süresi, 55-59 arasında olarak bildirilmiştir. Sunulan bu tez çalışmasından elde edilen sonuçlar, literatür ortalamalarında görünmektedir. Misel sarımı bazı çalışmalardan daha hızlı, bazılarından ise daha yavaş gerçekleşmiştir. Bu sonuçlarda, ortam etkisi açıkça görülebilmektedir. Deneme sonuçları ayrıca, en uzun misel gelişim süresinin sadece meşe kaba talaşından oluşan kontrol ortamından elde edildiğini göstermiştir. 


\section{Farklı Tarımsal Atıkların Ganoderma lucidum (Reishi mantarı) Yetiştiriciliğinde Verim ve Kalite Üzerine Etkisi}

Çizelge 1. Farklı ortamlara aşılanmış Reishi mantarının ortalama misel sarım süresi (gün)

\begin{tabular}{lll}
\hline Yetiştiricilik ortamları & $\begin{array}{l}\text { Misel sarım süresi } \\
\text { (gün) }\end{array}$ \\
\hline K & $44.67 \mathrm{a}$ & \\
B1 & $42.00 \mathrm{c}$ & \\
B2 & $43.33 \mathrm{~b}$ & \\
B3 & $28.00 \mathrm{~g}$ & \\
B4 & $40.00 \mathrm{~d}$ & \\
B5 & $38.00 \mathrm{e}$ & \\
B6 & $28.00 \mathrm{~g}$ & \\
B7 & $32.67 \mathrm{f}$ & \\
\hline
\end{tabular}

LSDort $* * *=0.87$

1. Aynı sütunda ayrı harflerle gösterilen ortalamalar arasındaki istatistiksel farklılıklar önemli bulunmuştur.

2. Ö.D.. Önemli değil; *. $\mathrm{P}<0.05$. **p $\leq 0.01$. ***p $\leq$ 0.001 'i ifade etmektedir.

\section{Farklı Ortamlara Aşılanmış Reishi Mantarının Biyolojik Etkinlik Oranı}

Biyolojik etkinlik (BE), kompost bileşenlerine, misel ırkına ve ekolojik faktörlere bağlı olarak değişiklik gösterebilir (Barreto ve ark., 2008). BE oran1, \%16.37 ile en yüksek B4, en düşük ise \%5.31 ile $\mathrm{K}$ ortamlarında belirlenirken, B2 ortamında biyolojik etkinlik gözlemlenmemiştir (misel sarımı gerçekleşmemesi nedeniyle) (Çizelge 2).

Pekşen ve Yakupoğlu (2009) tarafindan $G$. lucidum mantarında çay atıklarında yapılan bir denemede, biyolojik etkinlik oran1 \%31-\%34.90 arasında bulunmuştur. Roy ve ark. (2015) tarafindan $G$. lucidum mantarında yapilan çalışmada, farklı talaş tiplerinde biyolojik etkinlik \%0 (pirinç ve buğday kepeği ile Tectone grandis, pirinç ve buğday kepeği ile Gmelina arborea, pirinç ve buğday kepeği ile Michelia chambaca) ile \%7.6 (buğday kepeği ile birlikte Swietenia mahagoni) arasında hesaplanmıştır. Bernabé-González ve ark. (2015) iki farklı Reishi rkk ile yaptıkları denemede, biyolojik etkinlik oranını \%6.9 ile $\% 8.2$ arasında bulmuşlardır. Veena ve Pandey (2011), G. lucidum'da biyolojik verimliliği, $\% 25.7$ (\%90 çeltik samanı: \%10 pirinç kepeği) ile \%29.9 (\%22.5 talaş, \%67.5 çeltik samanı, $\% 10$ pirinç kepeği) arasında tespit etmişlerdir. Buğday kepeği, pirinç kepeğine göre daha iyi verim ve $\mathrm{BE}$ ile sonuçlanmıştır. Jeewanthi ve ark. (2017), G. lucidum'da biyolojik etkinliği, $\% 2.5$ (Kauçuk:Jak meyvesi) ile \%5.7 (Kauçuk:Tespih ağaci) arasında hesaplamışlardır. Çalışmalarında, Jack meyvesi ilavesi, daha düşük BE'ye neden olmuştur. Atila (2020), BE'nin \%8.9 (pamuk tohumu küspesi) ile \%24.7 (meşe talaşı) arasında değiştiğini tespit etmiştir. Sunulan bu çalışmada ise farklı bir şekilde en düşük sonuç sadece meşe kaba talaşından oluşan kontrol uygulamasından elde edilmiştir. Elde edilen sonuçlar literatür ile kıyaslandığında, kimi çalışmalardan daha yüksek, kimi çalışmalardan ise daha düşük sonuçlar elde edildiği görülmektedir. Ancak, sadece kepekle mısır koçanı kullanımının önemli bir üstünlüğü olduğu göz ard1 edilmemelidir. $\mathrm{Bu}$, üreticiler açısından önemli bir sonuçtur. $\mathrm{Bu}$ tür çalışmalar mümkün olduğunda orman ağaçları talaşlarına olan ihtiyacın azaltılması, tarımsal atıkların en efektif şekilde değerlendirilmesi ile hem tarımsal atıktan yeni bir ürün elde edilmesi hem de çevre açısından sıfır atık hedefine katkı sağlanması amacıyla yapılmaktadır. Talaşsız, sadece tarımsal atıktan oluşan bir yetiştiricilik ortamından, üreticiler açısından önem arz eden bir parametre olan en yüksek biyolojik etkinlik oranının elde edilmesi, dikkate değer bir bulgudur. Farkl1 substratlardan, farklı sonuçların elde edilmesi beklenilen bir sonuçtur. Bu tür çalışmalarda hedef, en etkin substrat karışımlarını ve oranlarını bulmaktır.

Çizelge 2. Farklı ortamlara aşılanmış Reishi mantarının ortalama biyolojik etkinlik oran1 (\%)

\begin{tabular}{lll}
\hline Yetiştiricilik ortamları & $\begin{array}{l}\text { Biyolojik } \\
(\%)\end{array}$ & etkinlik \\
\hline K & $5.31 \mathrm{c}$ \\
B1 & $8.04 \mathrm{bc}$ & \\
B2 & A \\
B3 & $9.29 \mathrm{~b}$ \\
B4 & $16.37 \mathrm{a}$ \\
B5 & $9.63 \mathrm{~b}$ \\
B6 & $8.20 \mathrm{bc}$ \\
B7 & $9.80 \mathrm{~b}$ \\
\hline
\end{tabular}

LSDort $* * *=3.32$

1. Aynı sütunda ayrı harflerle gösterilen ortalamalar arasındaki istatistiksel farklılıklar önemli bulunmuştur.

2. Ö.D.. Önemli değil; *. $\mathrm{P}<0.05 . * * \mathrm{p} \leq 0.01 . * * * \mathrm{p} \leq$ 0.001 'i ifade etmektedir. 


\section{Farklı Tarımsal Atıkların Ganoderma lucidum (Reishi mantarı) Yetiştiriciliğinde Verim ve Kalite Üzerine Etkisi}

\section{A ürün alınamamış.}

\section{Farklı Ortamlara Aşılanmış Mantarının Verim Değerleri}

Farklı ortamların verim miktarları, Çizelge 3'de sunulmuştur. En yüksek verim; $66.58 \mathrm{~g} / \mathrm{kg}$ ile $\mathrm{B} 4$, en düşük verim ise $25.32 \mathrm{~g} / \mathrm{kg}$ ile $\mathrm{K}$ ortamında gerçekleşmiştir. Verim, biyolojik etkinlik ile orantılı şekilde sonuçlanmıştır.

Yakupoğlu ve Pekşen (2011), G. lucidum'da en yüksek verimi meşe talaşında $73.07 \mathrm{~g} / \mathrm{kg}$ olarak belirlemişlerdir. Subbu Lakshmi (2013), deniz mahsulleri ile şeker kamışı karışımından oluşan ortamdan, $64.78 \mathrm{~g} / \mathrm{kg}$ verim elde etmişlerdir. Roy ve ark. (2015), G. lucidum'da buğday kepeği içeren Swietenia mahagoni talaşında $235.2 \mathrm{~g} / \mathrm{kg}$ ile en yüksek verimi tespit etmişlerdir. Pirinç kepeği içeren aynı talaşta ise verim neredeyse yarıya düşmüş ve $132.9 \mathrm{~g} / \mathrm{kg}$ olmuştur. Dipterocarpur turbinatus talaşında da benzer sonuçlar gözlemlenmiştir. BernabéGonzález ve ark. (2015)'nın çalışmasında ise verim 40.9-47.9 $\mathrm{g} / \mathrm{kg}$ olarak bulunmuştur. Jeewanthi ve ark. (2017) G. lucidum' da mango talaşında $(49.3 \mathrm{~g})$ en yüksek verimi kaydederlerken, bunu kauçuk : mango (45.7 g) ve kauçuk talaşı (42.5 g) izlemiştir. En düşük verim ise $26.3 \mathrm{~g}$ ile kauçuk:jak meyvesi talaşında tespit edilmiştir. Mango talaşı, diğer talaş malzemelerine göre daha etkili görünmektedir. Atila (2020) tarafından yapılan çalışmada ise verim 28.6 ile $86.1 \mathrm{~g} / \mathrm{kg}$ arasında değişmiştir.

$\mathrm{Bu}$ çalışmadan elde edilen sonuçlar birkaç çalışma hariç, literatür sınırlarında görünmektedir. Ancak, biyolojik etkinlik kısmında da değinildiği gibi, sadece meşe kaba talaşından en düşük verimin, sadece tarımsal atıktan (mısır koçanı) ise en yüksek verimin elde edilmesi önemli bir sonuçtur. Bölgemiz ürünü olan (Çukurova Bölgesi) misır koçanıbulunma kolaylığı açısından değerlendirildiğinde, pratiğe aktarılabilir ve önerilebilir bir sonuçtur. Özellikle de verim parametresinin üreticiler açısından önemi göz önünde bulundurulduğunda ve sifir atık projelerine yoğunlaştığımız bugünlerde, bu sonuç oldukça önemli görünmektedir.
Çizelge 3. Farklı ortamlara aşılanmış Reishi mantarının toplam verim değerleri (g)

\begin{tabular}{ll} 
Yetiştiricilik ortamları & Verim $(\mathrm{g})$ \\
\hline K & $25.32 \mathrm{c}$ \\
B1 & $34.43 \mathrm{c}$ \\
B2 & A \\
B3 & $32.21 \mathrm{c}$ \\
B4 & $66.58 \mathrm{a}$ \\
B5 & $39.25 \mathrm{bc}$ \\
B6 & $32.17 \mathrm{c}$ \\
B7 & $49.55 \mathrm{~b}$ \\
\hline
\end{tabular}

LSDort $* * *=14.11$

1. Aynı sütunda ayrı harflerle gösterilen ortalamalar arasındaki istatistiksel farklılıklar önemli bulunmuştur.

2. Ö.D.. Önemli değil; *. $\mathrm{P}<0.05 .{ }^{* *} \mathrm{p} \leq 0.01 .{ }^{* * *} \mathrm{p} \leq$ 0.001 ' i ifade etmektedir.

3. A Ürün alınamamış.

\section{Farklı Ortamlara Aşılanmış Reishi Mantarının Mantar A ğırlığı}

Sap ve şapkanın birlikte terazide tartılması ile $g$ olarak belirlenen mantar ağırlıkları, Çizelge 4'de verilmiştir. Buna göre, B5 ve B6 ortamlarının ortalama mantar ağırlıkları açısından, istatistiksel olarak bir fark görülmemiştir. En yüksek mantar ağırlığı 19.73 $\mathrm{g}$ ile B4 ortamında, en düşük ise $12.09 \mathrm{~g}$ ile B1 ortamında belirlenmişsir.

Yen (2008), farklı talaş karışımlarında $G$. lucidum suşlarının ortalama mantar ağırlığının 11.38 ile $15.16 \mathrm{~g}$ arasında olduğunu belirlemiştir. Yakupoğlu ve Pekşsen (2011), G. lucidum'un ortalama mantar ağırlığının $7.99 \mathrm{~g}$ ile $31.19 \mathrm{~g}$ arasında değiştiğini bildirmişlerdir. Bernabé-González ve ark. (2015) yaptıkları çalışmada, G. lucidum'un ortalama mantar ağırlığının $40.9 \mathrm{~g}$ ve $47.9 \mathrm{~g}$ arasında dağılım gösterdiğini bulmuşlardır. Mantar ağırlığı ve ölçülerinde, elde edilen verileri literatürle kıyaslarken, kullanılan mantar ırkı da önem arz etmektedir. Elde edilen datalar, 1rkın şişe kültürü mü torba kültürü için mi geliştirildiğine göre farkl111k göstermektedir. 


\section{Farklı Tarımsal Atıkların Ganoderma lucidum (Reishi mantarı) Yetiştiriciliğinde Verim ve Kalite Üzerine Etkisi}

Çizelge 4. Farklı ortamlara aşılanmış Reishi mantarının ortalama mantar ağırlı $\breve{g} 1(\mathrm{~g})$

\begin{tabular}{ll}
\hline Yetiştiricilik ortamları & Mantar ağırlığ $(\mathrm{g})$ \\
\hline K & $15.21 \mathrm{bc}$ \\
B1 & $12.09 \mathrm{c}$ \\
B2 & A \\
B3 & $12.41 \mathrm{c}$ \\
B4 & $19.73 \mathrm{a}$ \\
B5 & $16.35 \mathrm{abc}$ \\
B6 & $16.37 \mathrm{abc}$ \\
B7 & $16.98 \mathrm{ab}$ \\
\hline
\end{tabular}

LSDort $*=4.40$
1. Aynı sütunda ayrı harflerle gösterilen ortalamalar arasındaki istatistiksel farklılıklar önemli bulunmuştur.

2. Ö.D.. Önemli değil; *. $\mathrm{P}<0.05 .{ }^{* *} \mathrm{p} \leq 0.01 .{ }^{* * *} \mathrm{p} \leq$ 0.001 'i ifade etmektedir.

3. A Ürün alınamamış.

\section{Farklı Ortamlara Aşılanmış Reishi Mantarının Şapka Çapı}

Şapka çapının kumpas ile ölçülmesiyle, mm değerinden sonuçlar elde edilmiştir (Çizelge 5).

B2 ve B6 ortamlarının mantar şapkaları, sağlıklı ölçümü olanaksı kılan şekilde olmaları nedeniyle şapka çapı ölçümü yapılamamıştır. En geniş mantar şapka çap1 $50.63 \mathrm{~mm}$ ile B5 ortamında, en düşük ise $45.23 \mathrm{~mm}$ ile $\mathrm{B} 4$ ortamında belirlenmiştir. Farklı ortamlardan elde edilen mantarların şapka çapları, B2 ve B6 ortamları hariç (ölçüm yapılamadığından) birbirlerine yakın bulunmuştur.

Yen (2008), farklı talaş karışımlarında $G$. lucidum suşlarının mantar çapı değerlerini 6.92 ile $9.12 \mathrm{~cm}$ arasında belirlemiştir. Veena ve Pandey (2011), G. lucidum'un ortalama şapka çapının 73 ile $93 \mathrm{~mm}$ arasında değiştiğini tespit etmişlerdir. Yakupoğlu ve Pekşen (2011), G. lucidum 'un şapka çapını en yüksek $84.5 \mathrm{~mm}$, en düşük ise $42.8 \mathrm{~mm}$ olarak kaydetmiștir. Atila (2020) ise G. lucidum'da çap1, 58.0 ile $92.4 \mathrm{~mm}$ arasında belirlemiştir. Daha önce de belirttiğimiz gibi bu tür çalışmalarda, mantarların ölçü ve ağırlıkları torba kültürü için mi şişe kültürü için mi geliştirildiklerine göre değişiklik gösterebilmektedir. Sadece kullanılan çeşit belirleyici değildir. Yetiştiricilik ortamı bileşeni ve ekolojik etmenlerin de etkileri önemlidir.
Çizelge 5. Farklı ortamlara aşılanmış Reishi mantarının ortalama mantar şapka çapı $(\mathrm{mm})$

\begin{tabular}{ll}
\hline Yetiştiricilik ortamları & Şapka çap1 $(\mathrm{mm})$ \\
\hline K & 46.30 \\
B1 & 45.78 \\
B2 & A \\
B3 & 45.60 \\
B4 & 45.23 \\
B5 & 50.63 \\
B6 & B \\
B7 & 49.95 \\
\hline
\end{tabular}
LSDort= Ö.D.

1. Aynı sütunda ayrı harflerle gösterilen ortalamalar arasındaki istatistiksel farklılıklar önemli bulunmuştur.

2. Ö.D.. Önemli değil; *. $\mathrm{P}<0.05 .{ }^{* *} \mathrm{p} \leq 0.01 .{ }^{* * *} \mathrm{p} \leq$ 0.001 ' i ifade etmektedir.

3. A Ürün alınamamış.

4. B Şekil bozukluğu.

\section{Ortamlara Aşılanmış Reishi Mantarının Şapka Kalınlığı}

Şapka kalınlığının kumpas ile ölçülmesiyle mm değerinden sonuçlar elde edilmiştir. (Çizelge 6). B2 ve B6 ortamlarının mantar şapka kalınlıkları, sağlıklı ölçümü olanaksız kılan şekilde olmaları nedeniyle, şapka kalınlığı ölçümü yapılamamıştır. En kalın şapka kalınlığ 1 $10.24 \mathrm{~mm}$ ile B4 ortamında, en düşük ise 8.68 $\mathrm{mm}$ ile $\mathrm{K}$ ortamında tespit edilmiştir. Farklı ortamlardan elde edilen mantarların şapka kalınlıkları, B2 ve B6 ortamları hariç (ölçüm yapılamadığından) birbirlerine yakın bulunmuştur.

Veena ve Pandey (2011), G. lucidum'un ortalama şapka kalınlığının 6.9 ila $8.1 \mathrm{~mm}$ arasında değiştiğini bildirmiştir. Atila (2020), G. lucidum'da şapka kalınlığını 6.0 ile $8.1 \mathrm{~mm}$ arasında kaydetmiştir ki, sunulan bu çalışmada da benzer sonuçlar elde edilmiştir.

Çizelge 6. Farklı ortamlara aşılanmış Reishi mantarının ortalama mantar şapka kalınlı̆̆ 1 (mm)

\begin{tabular}{ll}
\hline Yetiştiricilik ortamları & Şapka kalınlı̆̆ $(\mathrm{mm})$ \\
\hline K & 8.68 \\
B1 & 9.33 \\
B2 & A \\
B3 & 10.21 \\
B4 & 10.24
\end{tabular}




\section{Farklı Tarımsal Atıkların Ganoderma lucidum (Reishi mantarı) Yetiştiriciliğinde Verim ve Kalite Üzerine Etkisi}

\begin{tabular}{ll} 
B5 & 9.11 \\
B6 & B \\
B7 & 8.83 \\
\hline
\end{tabular}

LSDort= Ö.D.

1. Aynı sütunda ayrı harflerle gösterilen ortalamalar arasındaki istatistiksel farklılıklar önemli bulunmuştur.

2. Ö.D.. Önemli değil; *. $\mathrm{P}<0.05 . * * \mathrm{p} \leq 0.01 . * * * \mathrm{p} \leq$ 0.001 'i ifade etmektedir.

3. A Ürün alınamamış.

4. B Şekil bozukluğu.

Farklı Ortamlara Aşılanmış Reishi Mantarının Kuru Madde Miktarı

Çalışmamızda, Reishi mantarı aşılanmış ortamların, ortalama kuru madde miktarı, Çizelge 7'de verilmiştir. Alınan örneklerde yapılan analizlerde, kuru madde miktarında tüm ortamların değeri birbirine yakın bulunmuştur. Sadece, misel gelişimi gözlemlenmediği için B2 ortamının analizi yapılmamıştır. En yüksek kuru madde miktarı, \%25.24 ile B1 ortamında tespit edilmiş, en düşük ise B4 ortamında kuru madde \%22.13 olmuştur.

Literatürde G. lucidum'da kuru madde miktarı ile ilgili veri bulunamamıștır. $\mathrm{Bu}$ nedenle, kıyaslama yapılmamıştır. Diğer mantar türlerine birkaç örnek vermek gerekirse, Koçyiğit (1984) $P$. ostreatus'da kuru madde miktarının \%8.3814.75 değer aralığında olduğunu, Kurt (2008) ise $P$. sajor-caju'da kuru madde miktarının \%7.95-13.08 değer aralığında olduğunu bulmuşlardır.

Çizelge 7. Farklı ortamlara aşılanmış Reishi mantarının ortalama kuru madde miktarı (\%)

\begin{tabular}{ll}
\hline Yetiştiricilik ortamları & $\begin{array}{l}\text { Kuru madde miktarı } \\
(\%)\end{array}$ \\
\hline K & 23.75 \\
B1 & 25.24 \\
B2 & A \\
B3 & 22.79 \\
B4 & 22.13 \\
B5 & 22.95 \\
B6 & 23.92 \\
B7 & 24.14 \\
\hline
\end{tabular}

LSDort $* * *=$ Ö.D.

1 Aynı sütunda ayrı harflerle gösterilen ortalamalar arasındaki istatistiksel farklılıklar önemli bulunmuştur.
2 Ö.D.. Önemli değil; *. $\mathrm{P}<0.05 .{ }^{* *} \mathrm{p} \leq 0.01 .{ }^{* * *} \mathrm{p} \leq$ 0.001 'i ifade etmektedir.

3 A Ürün alınamamış.

\section{Ortamlara Așılanmış Reishi Mantarının Protein Miktarı}

Çizelge 8'de farklı ortamlardan elde edilen Reishi mantarlarının protein miktarı gösterilmiştir. Protein verileri, kuru örnekten elde edilen değerleri içermektedir. En yüksek protein miktarı \%48.56 ile B4 ortamından elde edilirken, en düşük \%23.80 ile $\mathrm{K}$ ortamında belirlenmiştir. Protein miktarı, önemli bir parametredir. Reishi mantarı direkt tüketilmediği ve daha çok tıbbi bileşikleri ile ön plana çıktığı için protein miktarı biraz geri planda kalmaktadır. Sonuçlar incelendiğinde, mısır koçanı içeren B4 ortamı, sadece meşe kaba talaşı içeren kontrolün nerdeyse iki katı proteine sahiptir. Buda önemli bir sonuç olarak karşımıza çıkmaktadır. Daha önceki kısımlarda da açıkladığımız gibi, değerlendirilen parametrelerin tarımsal atıkların yoğun olduğu karışımlarda yüksek çıkması arzu edilen bir durumdur.

Reishi mantarıyla ilgili literatür taramalarında, protein miktarı ile ilgili verilere rastlanmamıştır. Reishi mantarı, direk tüketilebilir bir mantar olmadığı için protein miktarının ölçülmemiş olması muhtemeldir. Genellikle, yenebilir mantarlarda ilk bak1lan parametrelerdendir. Sadece, Hsieh ve Yang (2004), C/N oran1 80 olan ortamlarda $G$. lucidum'un karpoforunda, ham protein miktarının fazla olduğunu bildirmișlerdir. Bazı mantar türlerinde protein miktarları; $P$. ostreatus'da \%17.04-21.37, P. sajor-caju'da $\% 18.62-20.15, \quad P$. sapidus'da \%23.28-26.51 (Küçükomuzlu ve Pekşen, 2005), Lycoperdon giganteum'da \%24.30, Lentinus subnudus'da $\% 5.80$ ve Pleurotus florida'da \%15.10 (Gbolagade, 2006; Dundar ve ark, 2008) olarak bulunmuştur. Protein miktarının, substrat bileşeninden etkilendiği unutulmamalıdır. 


\section{Farklı Tarımsal Atıkların Ganoderma lucidum (Reishi mantarı) Yetiştiriciliğinde Verim ve Kalite Üzerine Etkisi}

Çizelge 8. Farklı ortamlara aşılanmış Reishi mantarının ortalama protein miktarı (\%)

\begin{tabular}{ll}
\hline Yetiştiricilik ortamları & Protein miktarı (\%) \\
\hline K & $23.80 \mathrm{f}$ \\
B1 & $31.06 \mathrm{e}$ \\
B2 & A \\
B3 & $46.64 \mathrm{ab}$ \\
B4 & $48.56 \mathrm{a}$ \\
B5 & $44.89 \mathrm{~b}$ \\
B6 & $37.45 \mathrm{~d}$ \\
B7 & $41.74 \mathrm{c}$ \\
\hline
\end{tabular}

LSDort $* * *=2.38$
1. Aynı sütunda ayrı harflerle gösterilen ortalamalar arasındaki istatistiksel farklılıklar önemli bulunmuștur.

2. Ö.D.. Önemli değil; *. $\mathrm{P}<0.05 . * * \mathrm{p} \leq 0.01 . * * * \mathrm{p} \leq$ $0.001^{\prime} \mathrm{i}$ ifade etmektedir.

3. A Ürün alınamamıs.

\section{Ortamların Özelliklerinin Belirlenmesi Amacı ile Yapılan Analizler}

Denemede B2 ortamı hariç bütün ortamlarda misel sarımı gerçekleşmiş ve karpofor oluşumu görülmüştür. Bu nedenle B2 ortamı hariç, bütün ortamların nem ve $\mathrm{pH}$ analizleri yapılmıștır.

\section{Farklı Ortamların pH Miktarı}

Reishi mantarı yetiştiriciliği için kullanılan yetiştiricilik ortamlarının, üç farklı dönemde ve kendi aralarındaki interaksiyonunun ortalama pH değeri Çizelge 9' da sunulmuştur. pH değeri açısından varyans analizi sonucuna bakıldığında; dönem ve bunların interaksiyonları istatistiksel olarak önemli, ortamların ortalamaları ise önemli bulunmamıştır.

Ortam x dönem interaksiyonu arasındaki ilişki önemli bulunmuş, $\mathrm{pH}$ değeri en yüksek 6.32 ile sterilizasyon sonrası B6 ortam1, en düşük ise 4.19 ile misel gelişim sonrası B4 ortamlarında gerçekleşmiştir. Kullanılan ortamların, ortalama $\mathrm{pH}$ değerleri incelendiğinde; en yüksek değer 5.70 ile B6 ortamı, en düşük ise 5.16 ile B3 ortamlarında tespit edilmiştir. Sterilizasyon sonras1, misel gelişim sonrası, hasat sonrası olmak üzere üç farklı dönemde alınan numunelerden, her dönemin ortalama $\mathrm{pH}$ değerleri çıkarılmıștır. Üç farklı dönemin ortalama $\mathrm{pH}$ değerleri incelendiğinde, 6.10 ile en yüksek sterilizasyon sonrası, en düşük ise 4.75 ile misel gelişim sonrası görülmüştür. Ortamların ortalama $\mathrm{pH}$ değerlerinin, sterilizasyon sonrasinda azaldığ gözlemlenmiştir. Ancak, $\mathrm{K}$ ve B6 ortamları hariç diğer bütün ortamların misel gelişim sonrası $\mathrm{pH}$ değeri ile hasat sonrasi $\mathrm{pH}$ değerleri karşılaştırıldığında, $\mathrm{pH}$ değerinin arttı̆̆ 1 gözlemlenmiştir. $\mathrm{K}$ ve $\mathrm{B} 6$ ortamlarında ise durum azalış göstermiştir.

G. lucidum'da ortamın pH'sina yönelik Yakupoğlu ve Pekșen (2011) tarafından yapılan çalıșmada, odun yongası kullanılarak hazırlanan yetiştirme ortamlarının $\mathrm{pH}$ değerlerini 5.807.35 arasında, hizar tozu kullanılarak hazırlanan yetiştirme ortamlarında ise $\mathrm{pH}$ değerlerinin 5.70-7.05 arasında değiştiği tespit edilmiştir. Atila (2020), G. lucidum'da ortamların $\mathrm{pH}$ değerini 4.43 ile 6.42 arasında belirlemiştir.

pH'nın önemi ile ilgili farklı mantar türlerinde yapılan bir çalıșmada, Zadrazil (1978), Pleurotus türlerinde ortam pH'sının 4-8 aralığ 1 dışında olduğu durumlarda, misel ve mantar gelişiminin yavaşladığını tespit etmiştir. Sunulan bu çalıșmada da, tüm bunlara ek olarak pH farklı dönemlerde ölçülmüş, farklı dönemlerde, verimi ve kaliteyi etkileyecek bir artış ya da azalış olup olmadığı ortaya çıkarılmaya çalışılmıştır. pH'nın besin maddelerinin alımında önemli bir faktör olduğu unutulmamalıdır. $\mathrm{Bu}$ nedenle, yetiştiricilik ortamlarının $\mathrm{pH}$ 's1 önem arz etmektedir. Uygun pH'ya sahip olmayan yetiştiricilik ortamlarında, besin maddeleri yeterli düzeyde olsa bile alınamayabilir ve verim düşüklüğü yaşanabilir. Sunulan bu çalışmada en genel haliyle pH 4.19 ile 6.32 arasında dağılım göstermiştir. $\mathrm{Bu}$ değerler, normal aralıkta görünmektedir. Sekil 1'de yetiştiricilik ortamlarında gelişen Reishi mantarı örneği görülmektedir. 


\section{Farklı Tarımsal Atıkların Ganoderma lucidum (Reishi mantarı) Yetiştiriciliğinde Verim ve Kalite Üzerine Etkisi}

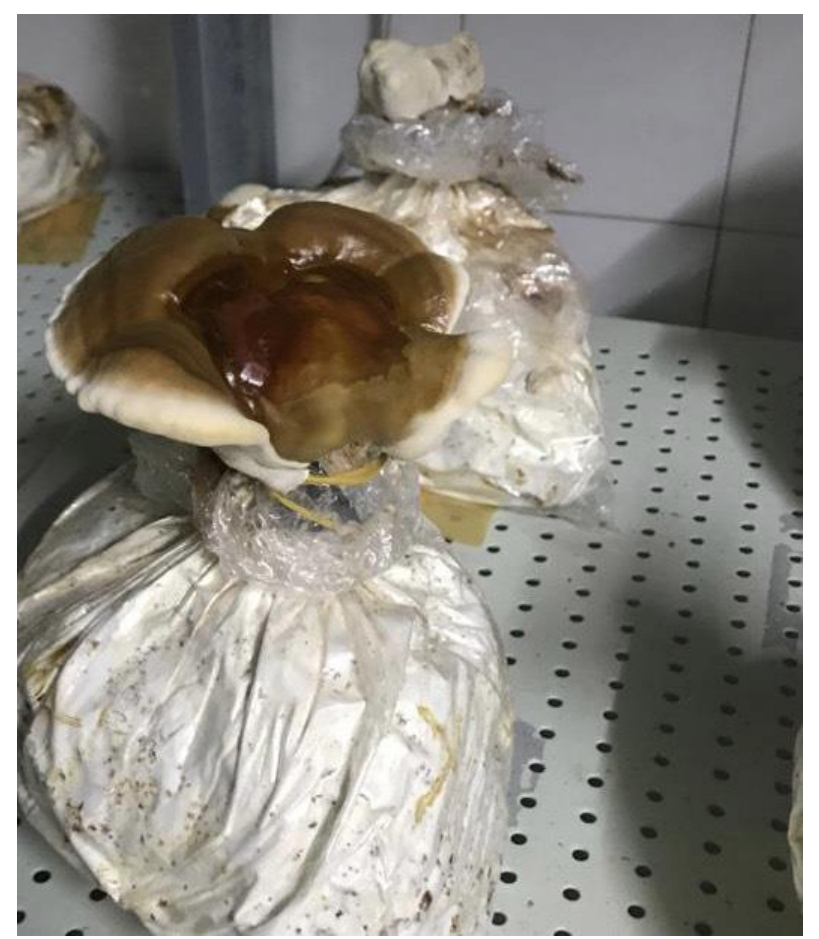

Şekil 1. Denenen yetiştiricilik ortamlarında gelişen G. lucidum mantarı örneği

Çizelge 9. Farklı ortamlara aşılanmış Reishi mantarının farklı ortam ve dönemlerde belirlenen pH miktarları

\begin{tabular}{|c|c|c|c|c|}
\hline \multirow[b]{2}{*}{$\begin{array}{l}\text { Yetiştiricilik } \\
\text { ortamları }\end{array}$} & \multicolumn{4}{|l|}{ Dönem } \\
\hline & $\begin{array}{l}\text { Sterilizasyon } \\
\text { sonras1 }\end{array}$ & $\begin{array}{l}\text { Misel gelişim } \\
\text { sonras1 }\end{array}$ & $\begin{array}{l}\text { Hasat } \\
\text { sonras1 }\end{array}$ & Ortalama \\
\hline $\mathrm{K}$ & $5.96 \mathrm{~b}$ & $5.20 \mathrm{~h} 1$ & $4.47 \mathrm{~m}$ & 5.21 \\
\hline B1 & $5.83 \mathrm{c}$ & $4.69 \mathrm{kl}$ & $4.99 \mathrm{j}$ & 5.17 \\
\hline B2 & $6.25 \mathrm{a}$ & $4.59 \mathrm{~lm}$ & $6.23 \mathrm{a}$ & 5.69 \\
\hline B3 & $5.93 \mathrm{bc}$ & $4.48 \mathrm{~m}$ & $5.08 \mathrm{ij}$ & 5.16 \\
\hline B4 & $6.27 \mathrm{a}$ & $4.19 n$ & $5.51 \mathrm{de}$ & 5.32 \\
\hline B5 & $6.04 \mathrm{~b}$ & $4.81 \mathrm{k}$ & $5.60 \mathrm{~d}$ & 5.49 \\
\hline B6 & $6.32 \mathrm{a}$ & $5.42 \mathrm{ef}$ & $5.36 \mathrm{fg}$ & 5.70 \\
\hline B7 & $6.21 \mathrm{a}$ & 4.661 & $5.29 \mathrm{gh}$ & 5.38 \\
\hline Ortalama & $6.10 \mathrm{~A}$ & $4.75 C$ & $5.32 B$ & \\
\hline
\end{tabular}

1. Aynı sütunda ayrı harflerle gösterilen ortalamalar arasındaki istatistiksel farklılıklar önemli bulunmuştur.

2. Ö.D.. Önemli değil; *. $\mathrm{P}<0.05$. **p $\leq 0.01$. ***p $\leq 0.001$ 'i ifade etmektedir.

\section{Ortamların Nem Miktarı}

Reishi mantarı için kullanılan ortamların, üç farklı dönemde ve kendi aralarındaki interaksiyonunun ortalama nem miktarı tespit edilmiştir (Çizelge 10). Nem miktarı açısından varyans analizi sonucuna bakıldığında; ortamlar, dönem ve bunların interaksiyonları arasındaki istatistiksel değerler önemli bulunmuştur. En yüksek nem oranı misel gelişim sonrası \%71.97 ile B1 ortamında, en düşük nem oran1 ise hasat sonras1 $\% 53.53$ ile B7 ortamında tespit edilmiştir. Diğer ortamların nem değeri, bu değerler arasında dağılım göstermiştir.

Sterilizasyon sonras1, misel gelişim sonras1, hasat sonrası olmak üzere üç farklı dönemde alınan örneklerden, her dönemin ortalama nem değerleri kaydedilmiştir. Üç farklı dönemin 


\section{Farklı Tarımsal Atıkların Ganoderma lucidum (Reishi mantarı) Yetiştiriciliğinde Verim ve Kalite Üzerine Etkisi}

ortalama nem değerleri incelendiğinde, $\% 66.42$ ile en yüksek misel gelişim sonrası, en düşük ise \%61.27 ile hasat sonrası görülmüștür.

Kullanılan yetiştiricilik ortamlarının her birinden, üç farklı dönemde alınan örneklerle nem miktarları belirlenmiştir. Her ortam kendi içerisinde, bu üç dönemde bulunan nem miktarları toplanarak üçe bölünmüş ve her ortamın ortalama nem değeri hesaplanmıştır. Ortamların, ortalama nem değerleri kıyaslandığında en yüksek nem değeri $\% 68.33$ ile B2 ortamında tespit edilirken, \%57.81 nem değeri ile en düşük B7 ortamında kaydedilmiştir.

Ortamların nem miktar1; mantarların misel gelișimi, karpofor oluşumu ve gelișimi aşamasında çok önemlidir. Nem değerinin çok düşük olduğu ortamlarda misel gelişimi olumsuz etkilenirken, tam tersi yüksek olduğu durumlarda da enfeksiyon oluşma riski dolayısıyla da olumsuz etkilenmektedir. Scrase ve Elliott (1998), odun substratlarında misel sarımı için optimum nem miktarının \%35-60, diğer materyallerden oluşan substratlarda ise misel sarımı için optimum nem miktarının \%60-80 olmas1 gerektiğini bildirmișlerdir. Yang ve ark. (2003), G. lucidum'un karpofor oluşumu için optimum nem içeriğinin \%60 olduğunu bildirmişlerdir. G. lucidum yetiştiriciliğini çay atıklarında deneyen Pekşen ve Yakupoğlu (2009), ortamların nem içeriklerinin \%67.03-72.71 arasında değiştiğini tespit etmişlerdir. Yakupoğlu ve Pekşen (2011), bir başka çalışmada G. lucidum'u odun ve hızar atıklarında denemiş ve ortamların nem miktarının, \%60.93-63.01 değerleri arasında dağılım gösterdiğini bildirmişlerdir. Atila (2020), G. lucidum'un nem içeriğini \%63.12 ile \%69.3 arasında belirlemiștir. Sunulan bu çalıșma sonuçları, \%53.53 ile \%71.97 arasında değişmiştir. Değerler; misel sarımı, primordium oluşumu ve mantar gelişimi için uygun görünmektedir. $\mathrm{Bu}$ çalışmada diğer çalışmalardan farklı olarak, nem ölçümü farklı dönemlerde tekrarlanarak artış ve azalışlar ortaya konulmaya çalış1lmıştır.

Çizelge 10. Farklı ortamlara aşılanmış Reishi mantarının farklı ortam ve dönemlerde belirlenen nem miktarları (\%)

\begin{tabular}{lllll}
\hline \multirow{2}{*}{$\begin{array}{l}\text { Yetiştiricilik } \\
\text { ortamlar1 }\end{array}$} & Dönem & \multicolumn{3}{l}{} \\
\cline { 2 - 5 } & $\begin{array}{l}\text { Sterilizasyon } \\
\text { sonras1 }\end{array}$ & $\begin{array}{l}\text { Misel } \\
\text { sonras1 }\end{array}$ & $\begin{array}{l}\text { gelişim } \\
\text { Hasat } \\
\text { sonras1 }\end{array}$ & Ortalama \\
\hline $\mathrm{K}$ & $62.71 \mathrm{fg}$ & $61.79 \mathrm{gh}$ & $56.61 \mathrm{j}$ & $60.37 \mathrm{CD}$ \\
$\mathrm{B} 1$ & $60.12 \mathrm{~h} 1$ & $71.97 \mathrm{a}$ & $61.38 \mathrm{gh}$ & $64.49 \mathrm{ABC}$ \\
$\mathrm{B} 2$ & $65.17 \mathrm{de}$ & $71.00 \mathrm{a}$ & $68.81 \mathrm{~b}$ & $68.33 \mathrm{~A}$ \\
$\mathrm{~B} 3$ & $67.78 \mathrm{bc}$ & $68.67 \mathrm{~b}$ & $63.94 \mathrm{ef}$ & $66.80 \mathrm{AB}$ \\
$\mathrm{B} 4$ & $67.90 \mathrm{bc}$ & $66.41 \mathrm{~cd}$ & $63.11 \mathrm{fg}$ & $65.81 \mathrm{AB}$ \\
$\mathrm{B} 5$ & $66.92 \mathrm{bcd}$ & $67.92 \mathrm{bc}$ & $62.83 \mathrm{fg}$ & $65.89 \mathrm{AB}$ \\
$\mathrm{B} 6$ & $61.60 \mathrm{gh}$ & $65.08 \mathrm{de}$ & $59.92 \mathrm{~h} 1$ & $62.21 \mathrm{BCD}$ \\
B7 & $61.34 \mathrm{gh}$ & $58.55 \mathrm{ij}$ & $53.53 \mathrm{k}$ & $57.81 \mathrm{D}$ \\
Ortalama & $64.19 \mathrm{~A}$ & $66.42 \mathrm{~A}$ & $61.27 \mathrm{~B}$ & \\
\hline \multicolumn{2}{c}{ LSDdön**=0.74 } & LSDort**=1.21 & LSDdönxort***=1.97
\end{tabular}

1 Aynı sütunda ayrı harflerle gösterilen ortalamalar arasındaki istatistiksel farklılıklar önemli bulunmuştur 2 Ö.D.. Önemli değil; *. $\mathrm{P}<0.05{ }^{* *} \mathrm{p} \leq 0.01 . * * * \mathrm{p} \leq 0.001$ ' $\mathrm{i}$ ifade etmektedir

\section{Sonuç ve Öneriler}

Denemede, farklı tarımsal atıklar kullanılarak, ortamların Reishi mantarının verim ve kalitesi üzerine etkileri incelenmiştir. B2 ortamı hariç, diğer tüm ortamlardan mantar elde edilmiştir. B2 ortamindan mantar elde edilememesinin, ortam ile tür ya da kullanılan irk arasında pozitif yönlü bir ilişki olmamasından kaynaklı olduğu düşünülmektedir. B3 ortamında, B2 ortamında kullanılan yer fistığı kabuğu, meșe kaba talaşı ile 1:1 oranında karıştırılmış ve mantar oluşumu gözlemlenmiştir. Bu durumda, sadece yer fistığı kabuğunun $G$. lucidum yetiştiriciliği için uygun substrat olmadığı, 


\section{Farklı Tarımsal Atıkların Ganoderma lucidum (Reishi mantarı) Yetiştiriciliğinde Verim ve Kalite Üzerine Etkisi}

mutlaka başka substratlar kullanılarak denenmesi gerektiği izlenimini oluşturmuştur.

Yetiştiricilik ortamları incelendiğinde; sadece meşe kaba talaşından oluşan kontrol uygulaması, optimum yetiştiricilik için verim ve biyolojik etkinlik açısından çok uygun görünmemektedir. Verim ve biyolojik etkinlik üreticiler açısından en önemli parametrelerdendir. En yüksek verim ve biyolojik etkinlik, buğday kepeği ile misır koçanı karışımından oluşan B4 ortamından elde edilmiştir. Mısır koçanından olumlu sonuç alınması, mısır yetiştiriciliğinin yoğun yapıldı $\breve{g} 1$ ülkemiz için olumlu bir sonuçtur. Mantar yetiştiriciliğinde, kolay ulaşılabilir atıkların kullanımı ekonomik açıdan önemlidir. Ayrıca, bölgelerde bolca atığ olumlu sonuç elde edilmesi sürdürülebilirlik, sıfir atık hedefi ve üreticileri üretime teşvik açısından önemlidir.

B3 ve B6 ortamlar1, en hizlı misel sarımı (28 gün) görülen ortamlardır. Ancak, bu ortamların verimleri ve biyolojik etkinlikleri, misel sarım süresinde olduğu kadar iyi olmamıştır. K ortamından sonra, verim yönünden en düşük iki ortam olmuşlardır. Misel gelişim hızı, erkencilik açısından önemli bir parametredir. Ancak, üreticiler açısından verim ve biyolojik etkinlik daha önemli bir parametredir. $\mathrm{Bu}$ nedenle, daha sonraki çalışmalarda hem erkencilik hem de verim ve biyolojik etkinliği artırıcı reçetelere gidilebilir. En yüksek verimin alındığ1 B4 ortam1 2 mısır koçan1 +1 kepek, en hızlı misel sarımı gerçekleşen ortamlardan bir tanesi olan B3 ise 1 meşe kaba talaşı +1 yer fistığ1 kabuğu +1 kepekten oluşmaktadır. Bu sonuçlar, gelecek çalışmalar için değerlendirilebilir.

$\mathrm{Bu}$ denemede, yetiştirme ortamların hazırlanması ile ilk hasada kadar geçen süre, 65-70 gün olarak hesaplanmıştır. Bir sonraki hasat için ise yaklaşık olarak, 15-20 gün geçmesi gerektiği belirlenmiştir.

G. lucidum'un yetiştiriciliği üzerine çalışmaların sınırlı olması ve ticari olarak fazla üretilmemesinden kaynaklı veri ve bilgiler kısıtlıdır. Her ne kadar sağlık açısından ön plana çıksa da direkt tüketilmediği için, yenebilir diğer mantarlara göre yetiştiriciliğine daha az yoğunlaşılmıştır. Bu çalışma ile yetiştiriciliği üzerine yeni bilgiler eklenmiştir. Substrat olarak Çukurova Bölgesi'nin ürünlerden asma budama atığ1, yer fistığ1 kabuğu ve misır koçanı değerlendirilmiştir. Bölgesel atıkların değerlendirilmesi, bölge üreticilerine verilecek tavsiyelerde bulunma kolaylığı açısından ve bölgede fazla yetiştirilen ürünlerin atıklarının değerlendirilmesi açısından, yani sıfır atık açısından önemlidir. Unutulmaması gereken diğer noktada, son iki yıldır yaşadığımız Covid-19 pandemisi, bağ1şıklık sisteminin mümkün olduğunca güçlü tutulmasının önemini tekrar ortaya koymuştur. G. lucidum mantarı, tıbbi bileşim yönünden ve bağışıklığı destekleyici rolü nedeniyle üzerinde en fazla çalıșılan mantar türlerindendir. $\mathrm{Bu}$ nedenle, yetiştiriciliğinin mümkün olduğunca aydınlatılması önemlidir. Farklı atıklar ve oranlarla çalışmalara devam edilmesi gerekmektedir.

\section{Teşekkür}

Bu çalışma, Ç.Ü. Araştırma Projeleri Biriminin FYL-2019-12318 No'lu Yüksek Lisans Tezi Projesinden Üretilmiştir.

\section{Kaynaklar}

Ağaoğlu, Y., İlbay, M. E., Uzun, A. (1992) Değișik Talaş + Kepek Karıșımlarının Pleurotus sajor-caju'nun Verimi Üzerine Etkileri. Türkiye 4.Yemeklik Mantar Kongresi, II. Cilt, 2-4 Kasim 1992, Yalova.

Anonim (2019) Agroma Mantar. www.agromantar.com

Atila, F. (2020) Comparative study on the mycelial growth and yield of Ganoderma lucidum (Curt.: Fr.) Karst. on different lignocellulosic wastes. Acta Ecologica Sinica 40:153-157. doi: 10.1016/j.chnaes.2018.11.007

Barreto, S. M., Lopez, M. V., Levin, L. (2008) Effect of culture parameters on the production of the edible mushroom Grifola frondosa (maitake) in tropical weathers. World J Microbiol Biotechnol 24:1361. doi: 10.1007/s11274-007-9616$\mathrm{Z}$

Bernabé-González, T., Cayetano-Catarino, M., Bernabé-Villanueva, G., Romero-Flores, 


\section{Farklı Tarımsal Atıkların Ganoderma lucidum (Reishi mantarı) Yetiştiriciliğinde Verim ve Kalite Üzerine Etkisi}

A., Ángel-Ríos, M. D., Pérez-Salgado, J. (2015) Cultivation of Ganoderma lucidum on Agricultural By-Products in Mexico. Micologia Aplicada International 27(2):25-30.

Bilgir, B., Boztok, K. (1983) Kültür Mantarı (Agaricus bisporus L. Sing)'nın Besin Değeri Üzerine Araştırma. Ege Üniversitesi Ziraat Fakültesi Dergisi 20(1):9-17.

Bozok, F., Eker, T., Sezer, G., Bozdoğan, A., Doğan, H. H., Büyükalaca, S. (2016) Investigation of Antioxidant Potential and Phytotoxic Effects of Ganoderma lucidum Methanol Extract. Turkish Journal of Agriculture-Food Science and Technology 4(3):163-170. doi: 10.24925/turjaf.v4i3.163-170.568

Chang, S. T., Buswell, J. A. (1996) Mushroom Nutriceuticals. World J Microb Biotechnol 12:473-476. doi: 10.1007/BF00419460

Dundar, A., Acay, H., Yildiz, A. (2008) Yield performances and nutritional contents of three oyster mushroom species cultivated on wheat stalk. Afr J Biotechnol 7:34973501.

Erkel, E. I. (2009a) The effect of different substrate mediums on yield of Ganoderma lucidum (Fr.) Karst. J Food Agric Environ 77:841-844.

Erkel, I. E. (2009b) Yield Performance of Ganoderma lucidum (Fr.) Karst Cultivation on Substrates Containing Different Protein and Carbohydrate Sources. African J Agric Res 4(11):13311333.

Gbolagade, J. S. (2006) Bacteria associated with compost used for cultivation of Nigerian edible mushrooms Pleurotus tuber-regium (Fr.) Singer, and Lentinus squarrosulus (Berk.). Afr J Biotechnol 5:338-342.

Gurung, O. K., Budathoki, U., Parajuli, G. (2012) Effect of Different Substrates on the Production of Ganoderma lucidum (Curt.:Fr.) Karst. Our Nature 10:191198. doi: 10.3126/on.v10i1.7781

Hsieh, C., Yang, F. C. (2004) Reusing soy residue for the solid-state fermentation of
Ganoderma lucidum. Bioresource Technol 91:105-109. doi: 10.1016/s09608524(03)00157-3

İlbay, M. E. (1994) Lentinus edodes Kültür Mantarı Yetiştiriciliğinde Değişik

Yetiştirme Ortamları ve Katk1 Maddelerinin Verim ve Kaliteye Etkileri Üzerinde Araştırmalar. Doktora Tezi, Ankara Üniversitesi.

Jeewanthi, L. A. M. N., Ratnayake, K., Rajapakse, P. (2017) Growth and Yield of Reishi Mushroom [Ganoderma lucidum (Curtis) P. Karst] in Different Sawdust Substrates. Journal of Food and Agriculture 10(1\&2):8-16. doi: 10.4038/jfa.v10i1-2.5208

Kacar, B. (1972) Bitki ve Toprağın Kimyasal Analizleri, II. Bitki Analizleri. Ankara Üniversitesi Ziraat Fakültesi Yayınları, No: 453, Ankara.

Koçyiğit, A. E., (1984) Kayın Mantarı (Pleurotus ostreatus) Türünde Misel Geliştirme ve Primordium Oluşturma Dönemlerinde Uygulanan Farklı Sicaklık ve Işı1k Düzeylerinin Verim ve Kaliteye Etkisi Üzerinde Araştırmalar. Doktora Tezi, Ankara.

Küçükomuzlu, B., Pekşen, A. (2005) Yetiştirme ortamı ağırlıklarının Pleurotus mantar türlerinin verim ve kalitesi üzerine etkileri. Ondokuz Mayls Üniversitesi Ziraat Fakültesi Dergisi 20(3) 64-71.

Kurt, Ş. (2008) Değișik Tarımsal Artıkların Kayın Mantar1 (Pleurotus ostreatus, Pleurotus sajor-caju) Yetiştiriciliğinde Kullanım Olanakları. Doktora Tezi, Enstitüsü, Adana.

Lincoof, G. H. (1988) The Audubon Society Field Guide to North American Mushrooms. Chanticleer Press, New York.

Matilla, P., Salo-Väänänen, P., Könkö, K., Aro, H., Jalava, T. (2002) Basic Composition and Amino Acid Contents of Mushrooms Cultivated in Finland. J Agric Food Chem 50(22):6419-6422.

Peksen, A., Yakupoglu, G. (2009) Tea waste as a supplement for the cultivation of Ganoderma lucidum. World J Microbiol 


\section{Farklı Tarımsal Atıkların Ganoderma lucidum (Reishi mantarı) Yetiştiriciliğinde Verim ve Kalite Üzerine Etkisi}

Biotechnol 25(4):611-618. doi: 10.1007/s11274-008-9931-z

Roy, S., Jahan, M. A. A., Das, K. K., Munshi, S. K., Noor, R. (2015) Artificial Cultivation of Ganoderma lucidum (Reishi Medicinal Mushroom) Using Different Sawdusts as Substrates. American Journal of BioScience 3(5):178-182. doi: 10.11648/j.ajbio.20150305.13

Sánchez, C. (2004) Modern aspects of mushroom culture technology. Appl Microbiol Biotechnol 64(6):756-62. doi: 10.1007/s00253-004-1569-7

Scrase, R. J., Elliott, T. J. (1998) Biology and Technology of Mushroom Culture: Microbiology of Fermented Foods, Vol 2. B. J. B. Wood (Ed.), 543-584, Blackie Academic Professional, London.

Shen, Q., Royse, D. J. (2002) Effects of genotypes of maitake (Grifola frondosa) on biological efficiency, quality and crop cycle time. Appl Microbiol Biotechnol 58(2):178-82. doi: $10.1007 / \mathrm{s} 00253-001-$ 0875-6

Smith, J. E., Rowan, N. J., Sullivan, R. (2002) Medicinal Mushrooms: Their therapeutic properties and current usage with special emphasis on cancer treatments. University of Strathclyde \& Cancer Research, UK.

Subbu Lakshmi, S. (2013) In vivo Utilization of Seafood Processing Wastes for Cultivation of the Medicinal Mushroom (Ganoderma lucidum) Using AgroIndustrial Waste. Asian Journal of Pharmaceutical and Clinical Research 6(4):51-54.
Veena, S. S., Pandey, M. (2011) Paddy straw as a substrate for the cultivation of Lingzhi or Reishi medicinal mushroom, Ganoderma lucidum (W.Curt.:Fr.) P. Karst. in India. Int J Med Mushrooms 13(4):397-400. doi: 10.1615/intjmedmushr.v13.i4.100

Yakupoğlu, G., Pekşen, A. (2011) Çay Atığından Hazırlanan Farklı Kompost ve Partikül Büyüklügünün Ganoderma lucidum Mantarının Verimi ve Bazı Morfolojik Özellikleri Üzerine Etkisi. Ekoloji 20(78):41-47. doi: 10.5053/ekoloji.2011.787

Yang, F. C., Hsieh, C., Chen, H. M. (2003) Use of stillage grain from a rice-spirit distillery in the solid state fermentation of Ganoderma lucidum. Process Biochem 39(1):21-26. doi: 10.1016/S00329592(02)00255-8

Yen, F. (2008) Farklı Ganoderma lucidum Suşlarının Sivı ve Katı Besin Ortamlarında Misel ve Karpofor Gelişimi ile Verim ve Bazı Kalite Özelliklerinin Karşılaştırılması. Yüksek Lisans Tezi, Çukurova Üniversitesi Adana.

Zadrazil, F. (1978) Cultivation of Pleurotus: The Biology and Cultivation of Edible Mushroom. S. T. C. Chang, W. A. Hayes (Eds.), 521-554, Academic Press, New York.

Zhao, J. D., Zhang, X. Q. (1994) Importance, distribution and taxonomy of Ganodermataceae in China. Proceedings of Contributed Symposium, 59A, B, $5^{\text {th }}$ International Mycological Congress, Vancouver, 14-21 Ağustos 1994, pp. 1-2. 